\title{
Short Communication: Study of Immune Parameters in Three Greek Dairy Sheep Breeds During the Periparturient Period
}

\author{
G. Theodorou, S. Fragou, R. Chronopoulou, A. Kominakis, E. Rogdakis, and I. Politis ${ }^{1}$ \\ Department of Animal Science, Agricultural University of Athens, 11855 Athens, Greece
}

\begin{abstract}
The objective of the present study was to evaluate whether immunosuppression occurs in 3 different Greek dairy sheep breeds during the periparturient period. A total of 33 ewes from 3 breeds [i.e., the lowproducing Boutsiko breed $(\mathrm{n}=11)$, which is highly adaptable to harsh environments; the high-producing but environmentally fragile Chios breed $(\mathrm{n}=11)$; and an intermediate synthetic breed (50\% Boutsiko, 25\% Arta, and 25\% Chios, $\mathrm{n}=11$ )] were used. Blood samples were collected at 18 and $2 \mathrm{~d}$ before parturition and at $15 \mathrm{~d}$ after parturition. Total cell-associated and membrane-bound urokinase plasminogen activator (U-PA) activity, free U-PA binding sites on cellular membranes, and superoxide anion (SA) production by activated phagocytes were determined. Results indicated that all immune parameters measured remained constant during the periparturient period for the Boutsiko breed. In contrast, there were reductions in total cellassociated and membrane-bound U-PA activity by both monocytes-macrophages and neutrophils and in SA production by monocytes-macrophages at $\mathrm{d} 2$ before parturition for the Chios breed. In the synthetic breed, there were reductions in total cell-associated and membranebound U-PA activity by monocytes-macrophages and in SA production by both monocytes-macrophages and neutrophils at d 15 after parturition. Thus, mild immunosuppression during the periparturient period was observed in the 2 breeds with the highest milk production. Key words: periparturient period, urokinase plasminogen activator, superoxide anion, ovine
\end{abstract}

Sheep farming is a very important animal production activity in Greece, contributing to approximately $40 \%$ of the sector's gross income (Hadjigeorgiou et al., 2002). Two typical indigenous breeds and a synthetic breed were used in this study. The Chios breed is characterized by high milk yield and litter size. On the other

Received March 30, 2007.

Accepted July 31, 2007.

${ }^{1}$ Corresponding author: i.politis@aua.gr hand, the Boutsiko breed is characterized by low milk yield, but it is known for its adaptability under harsh environmental conditions. Furthermore, the Boutsiko breed is less susceptible to mastitis (Hatziminaoglou et al., 1990; Simos et al., 1996; Kominakis et al., 1998; Ploumi et al., 1998). The synthetic breed (50\% Boutsiko, $25 \%$ Arta, and 25\% Chios) has been developed recently in an attempt to upgrade the Boutsiko breed by combining the high productivity of the Chios and Arta breeds with the robustness of the Boutsiko breed.

Several studies have demonstrated a decline in immune function during the periparturient period in dairy cows, but the causes of immunosuppression are not completely understood. It is certain, however, that immunosuppression has been linked to endocrine changes associated with parturition, metabolic stresses associated with lactogenesis, and availability of critical nutrients, including vitamin $\mathrm{E}$ and calcium (Kehrli and Goff, 1989; Goff and Horst, 1997; Smith et al., 1997; Kimura et al., 1999). To our knowledge, only one study has dealt partly with immunosuppression during the periparturient period in dairy sheep. Caroprese et al. (2006) reported that cell-mediated and humoral immune responses and plasma IL-6 concentrations underwent marked fluctuations in periparturient ewes. There is a major unfulfilled need for more studies on the suppression of the immune system in periparturient dairy sheep.

Phagocytes (monocytes-macrophages and neutrophils) are critical for a proper immune response, because these cells are capable of migrating from blood circulation to any infected or injured tissue to confront pathogens (Politis et al., 2002). The rapidity of the migratory response depends on the ability of phagocytic cells to overcome the mechanical barriers imposed by the basement membranes. To achieve this objective, monocytes-macrophages and neutrophils use limited proteolytic activity at the regions of contact with the endothelial cells. Ovine monocytes-macrophages and neutrophils express a specific urokinase-plasminogen activator (U-PA) receptor (CD 87; Politis et al., 2002). The U-PA can bind to this receptor and convert the abundant proteolytically inactive proenzyme plasmino- 
Table 1. Least squares means $( \pm \mathrm{SEM})$ of total cell-associated urokinase plasminogen activator (U-PA) activity of macrophages and neutrophils for the Boutsiko breed (B), the synthetic breed (S; $50 \%$ Boutsiko, 25\% Arta, and 25\% Chios), and the Chios breed (C)

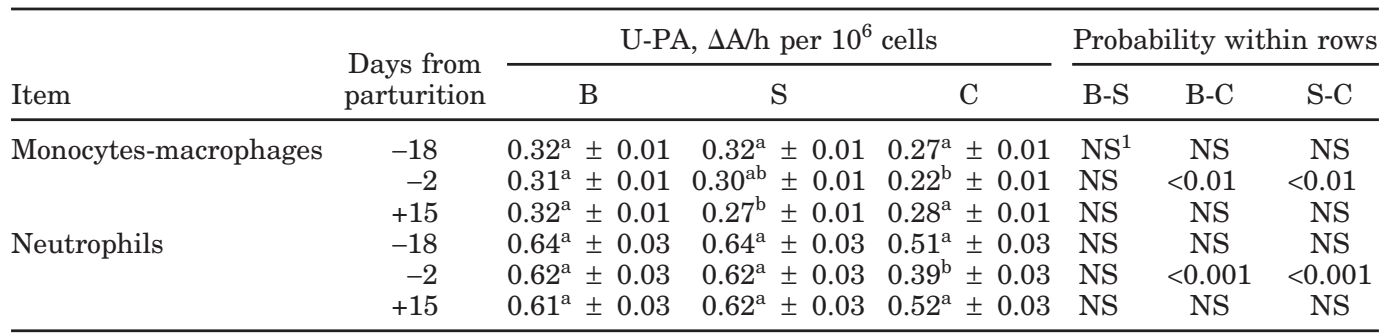

${ }^{\mathrm{a}, \mathrm{b}}$ Means within the same column and item followed by different letters differ at $P<0.01$.

${ }^{1} \mathrm{NS}=$ nonsignificant $(P>0.05)$.

gen to active plasmin. Plasmin is capable of degrading certain matrix components, in addition to activating other matrix-degrading enzymes such as metalloproteinases.

The objective of the present study was to determine changes in the dynamics of the U-PA system as well as in the production of superoxide anion (SA) by monocytes-macrophages and neutrophils in 3 Greek dairy sheep breeds during the periparturient period.

A total of 33 ewes were used in this study; 11 from the Boutsiko breed, 11 from the synthetic breed (50\% Boutsiko, 25\% Arta, and 25\% Chios), and 11 from the Chios breed. Animals were housed within the premises of the experimental farm of the Agricultural University of Athens. The ewes lambed between November 10, 2005, and January 10, 2006. Furthermore, all ewes lambed within $\pm 1 \mathrm{~d}$ of anticipated lambing. All ewes that lambed outside this period were excluded from the experiment.

Blood samples were collected from all ewes on 18 and $2 \mathrm{~d}$ before parturition and on d 15 after parturition. Monocytes-macrophages and neutrophils were isolated as described by Politis et al. (2002). Total cell-associated, membrane-bound U-PA activity and U-PA binding sites in activated monocytes-macrophages and neutrophils were determined by using the methods described by Politis et al. (2002). Activation of phagocytes is achieved following incubation with $81 \mu M$ phorbol myristate acetate for $30 \mathrm{~min}$ at $37^{\circ} \mathrm{C}$. Superoxide anion production by phagocytes, as a direct indicator of respiratory burst activation, was measured by using the superoxide dismutase-inhibitable reduction of ferricytochrome C. All details are as described by Politis et al. (1995).

Significant departures from normal distribution for all variables and possible outliers were initially assessed by using quantile-quartile plots. Calculation of the extreme Studentized deviates for all variables was performed according to Grubbs (1969), and outliers were excluded at a 2-tailed probability of 0.05 . Logarithmic transformation for SA production and for free UPA binding sites (by adding the value of 1 because of negative values) was then used in an attempt to meet ANOVA assumptions (i.e., normal distribution and homogeneity of variance within class effects). Transformed values of variables were then analyzed by using a linear mixed model appropriate for repeated measurements per subject (animal) with the compound symmetry for modeling the error covariance structure. The fixed effects part of the model included the effects of breed (Chios, synthetic, and Boutsiko), parturition stage (3 stages: $18 \mathrm{~d}$ before, $2 \mathrm{~d}$ before, and $15 \mathrm{~d}$ after parturition), and the breed by parturition stage interaction, whereas the effect of animal nested within breed was fitted as a random effect. The Satterthwaite method (Steel and Torrie, 1980) was used for computing the denominator degrees of freedom for the tests of fixed effects. The Tukey-Kramer adjustment was used for the $P$-values when performing multiple comparisons. Results of mixed ANOVA are presented as least squares means with standard errors. All mixed ANOVA analyses were carried out by PROC MIXED in SAS, version 9.0 (SAS Institute, 2004).

Total and membrane bound U-PA activities in monocytes-macrophages and neutrophils during the periparturient period for the 3 Greek dairy sheep breeds are presented in Tables 1 and 2, respectively. Total and membrane-bound U-PA activities remained constant during the periparturient period for the Boutsiko breed for both monocytes-macrophages and neutrophils. In contrast, there was a decline in total and membranebound U-PA activities of both monocytes-macrophages and neutrophils at $\mathrm{d} 2$ prior to parturition in the Chios breed. In the synthetic breed, the lowest values for total and membrane-bound U-PA activities of monocytesmacrophages were observed at d 15 after parturition, and the highest were observed at $d 18$ prior to parturition. There were no significant differences in total and 
Table 2. Least squares means ( \pm SEM) of membrane-bound urokinase plasminogen activator (U-PA) activity of macrophages and neutrophils for the Boutsiko breed (B), the synthetic breed (S; 50\% Boutsiko, 25\% Arta, and 25\% Chios), and the Chios breed (C)

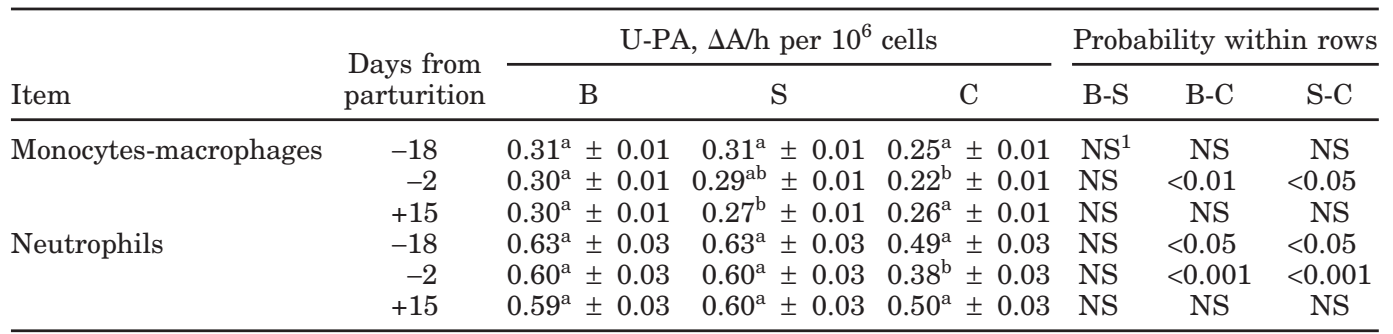

${ }^{\mathrm{a}, \mathrm{b}}$ Means within the same column and item followed by different letters differ at $P<0.05$.

${ }^{1} \mathrm{NS}=$ nonsignificant $(P>0.05)$.

membrane-bound U-PA activities of neutrophils isolated from the synthetic breed during the periparturient period.

Tables 1 and 2 also allow comparisons to be made among breeds. There were no significant differences $(P$ $>0.05$ ) in total and membrane-bound U-PA activities of monocytes-macrophages among breeds at d 15 after parturition and at d 18 before parturition. Furthermore, no significant differences were observed among breeds regarding total U-PA activity of neutrophils at d 15 after parturition and at d 18 before parturition and in membrane-bound U-PA activity of neutrophils at d 15 after parturition. In contrast, total and membranebound U-PA activities were lower in the Chios breed compared with the other 2 breeds for both monocytesmacrophages $(P<0.01)$ and neutrophils $(P<0.001)$ at d 2 before parturition and in neutrophils $(P<0.01)$ at d 18 before parturition.

Total U-PA activity was greater by 77 to $130 \%$ in neutrophils compared with the corresponding values in monocytes-macrophages. In a similar manner, membrane bound U-PA activity was greater by 73 to $122 \%$ in neutrophils than in monocyte-macrophages. The majority of the U-PA was detected in the cell membrane (Tables 1 and 2).

There were no significant differences $(P>0.05)$ in free U-PA binding sites of monocytes-macrophages and neutrophils during the periparturient period in all 3 Greek dairy sheep breeds used in our study. Furthermore, there were no significant differences $(P>0.05)$ between breeds in free U-PA binding sites on the membrane of monocytes-macrophages and neutrophils at all sampling points (d 18 and d 2 before and d 15 after parturition; data not shown).

Superoxide anion production of monocytes-macrophages and neutrophils during the periparturient period for the 3 Greek dairy sheep breeds is presented in Table 3. Superoxide anion production remained constant during the periparturient period for the Boutsiko breed for both monocytes-macrophages and neutrophils. In the Chios breed, the lowest value for SA production by monocytes-macrophages was observed at $d$ 2 prior to parturition and the highest at $\mathrm{d} 15$ after parturition. In contrast, there were no significant differences in SA production by neutrophils isolated from the Chios breed during the periparturient period. In the synthetic breed, there was a decline in SA production by monocytes-macrophages and neutrophils at d 15 after parturition. There were no significant differences $(P>$ 0.05) among breeds in SA production by monocytesmacrophages and neutrophils at $d 18$ before parturition and at $\mathrm{d} 15$ after parturition. Superoxide anion production by monocytes-macrophages and neutrophils was lower in the Chios breed compared with the other 2 breeds at $\mathrm{d} 2$ before parturition.

The first finding emerging from the current study was that 2 of the total of 3 Greek dairy sheep breeds exhibited signs of mild immunosuppression during the periparturient period. The 2 breeds affected were the Chios and the synthetic breed, but not the Boutsiko breed. It is particularly interesting that the 2 breeds affected were those with the highest milk production ability. A previous study from our group (Theodorou et al., 2007) involving the same group of ewes demonstrated that the Chios and the synthetic breed produced, respectively, 108 and $40 \%$ more milk than the Boutsiko breed. Except for the low milk production ability, the Boutsiko breed is characterized by its ability to tolerate the poor weather and harsh environmental conditions that occur in the mountainous regions of Greece. Even though a cause-and-effect relationship has not been established, we favor the hypothesis that immunosuppression in dairy sheep is milder in nature than that observed in dairy cows and that it occurs only in the high-producing breeds.

The second finding emerging from this study was that immunosuppression was more pronounced in the Chios breed, because both monocytes-macrophages and neu- 
Table 3. Least squares means ( $\pm \mathrm{SEM})$ of superoxide anion (SA) production of macrophages and neutrophils for the Boutsiko breed (B), the synthetic breed (S; $50 \%$ Boutsiko, $25 \%$ Arta, and $25 \%$ Chios), and the Chios breed (C) ${ }^{1}$

\begin{tabular}{|c|c|c|c|c|c|c|c|}
\hline \multirow[b]{2}{*}{ Item } & \multirow{2}{*}{$\begin{array}{l}\text { Days from } \\
\text { parturition }\end{array}$} & \multicolumn{3}{|c|}{$\mathrm{SA}, \mathrm{nmol} / 10^{6}$ cells } & \multicolumn{3}{|c|}{ Probability within rows } \\
\hline & & B & $\mathrm{S}$ & $\mathrm{C}$ & B-S & B-C & S-C \\
\hline \multirow[t]{2}{*}{ Monocytes-macrophages } & -18 & $0.43^{\mathrm{a}} \pm 0.02$ & $0.43^{\mathrm{a}} \pm 0.02$ & $0.35^{\mathrm{ab}} \pm 0.02$ & $\mathrm{NS}^{2}$ & NS & NS \\
\hline & +15 & $0.44^{\mathrm{a}} \pm 0.02$ & $0.35^{\mathrm{b}} \pm 0.02$ & $0.39^{\mathrm{a}} \pm 0.02$ & NS & NS & NS \\
\hline \multirow[t]{3}{*}{ Neutrophils } & -18 & $0.57^{\mathrm{a}} \pm 0.03$ & $0.59^{\mathrm{a}} \pm 0.03$ & $0.50^{\mathrm{a}} \pm 0.03$ & NS & NS & NS \\
\hline & -2 & $0.57^{\mathrm{a}} \pm 0.03$ & $0.56^{\mathrm{ab}} \pm 0.03$ & $0.43^{\mathrm{a}} \pm 0.03$ & NS & $<0.05$ & $<0.05$ \\
\hline & +15 & $0.56^{\mathrm{a}} \pm 0.03$ & $0.49^{\mathrm{b}} \pm 0.03$ & $0.50^{\mathrm{a}} \pm 0.03$ & NS & NS & NS \\
\hline
\end{tabular}

${ }^{\mathrm{a}, \mathrm{b}}$ Means within the same column and item followed by different letters differ at $P<0.05$.

${ }^{1}$ All values are $\log _{10}$ transformed.

${ }^{2} \mathrm{NS}=$ nonsignificant $(P>0.05)$.

trophils were affected. In the synthetic breed, immunosuppression was mainly observed in monocytes-macrophages (total and membrane-bound U-PA, SA), whereas in neutrophils only SA production was affected. The extent of immunosuppression observed in the 2 Greek dairy sheep breeds was less pronounced than that observed in dairy cows for the same time period. Politis et al. (2004) reported that SA production at parturition was less than $50 \%$ of that observed $4 \mathrm{wk}$ before and 4 wk after parturition. Similarly, Politis et al. (2001) reported that membrane-bound U-PA activity of neutrophils was in the range of 0.1 to $0.12 \Delta \mathrm{A} / \mathrm{h}$ per $10^{6}$ cells around parturition and $0.3 \Delta \mathrm{A} / \mathrm{h}$ per $10^{6}$ cells at $4 \mathrm{wk}$ after parturition. In contrast, reductions in the same parameters in our study never exceeded the level of $24 \%$. Mild immunosuppression occurred in the prepartum period in the Chios breed and in the postpartum period in the synthetic breed.

The nature of the factors inducing the mild immunosuppression observed in the 2 highest milk-producing Greek dairy sheep breeds is not known with certainty. The hormonal environment of the blood and extracellular tissue fluids can probably influence phagocyte function and activity. It is known that major hormonal changes occur around parturition in dairy sheep. Plasma concentrations of sex hormones in sheep change spectacularly as the animal approaches parturition; progesterone concentration falls dramatically, whereas cortisol and estradiol concentrations rise in a similar manner leading up to parturition (El-Belely et al., 2000). Fluctuation of these hormones negatively affects the function on the immune system, at least in the case of the dairy cow.

In conclusion, mild immunosuppression occurred in the 2 highest milk-producing breeds (Chios and synthetic) during the periparturient period, but not in the lower milk-producing but environmentally tolerant Boutsiko breed. The patterns of mild immunosuppression were different for these 2 breeds; for the Chios breed it occurred in the prepartum period, whereas for the synthetic breed it occurred in the postpartum period. Interactions in the physiology among reproduction, lactation, and immune function in the dairy sheep require further research.

\section{REFERENCES}

Caroprese, M., M. Albenzio, G. Annicchiarico, and A. Sevi. 2006. Changes occurring in immune responsiveness of single- and twinbearing Comisana ewes during the transition period. J. Dairy Sci. 89:562-568.

El-Belely, M. S., A. A. Al-Qarawi, and H. A. Abdel-Rahman. 2000 Interrelationships between the blood coagulation profile and plasma concentrations of progesterone, oestradiol- $17 \beta$ and cortisol throughout pregnancy and around parturition in sheep. J. Agric. Sci. 135:203-209.

Goff, J. P., and R. L. Horst. 1997. Physiological changes at parturition and their relationship to metabolic disorders. J. Dairy Sci. 80:1260-1268.

Grubbs, F. 1969. Procedures for detecting outlying observations in samples. Technometrics 11:1-21.

Hadjigeorgiou, I., F. Vallerand, K. Tsimpoukas, and G. Zervas. 2002. The socio-economics of sheep and goat farming in Greece and the implications forfuture rural development. Options Méditerranéennes, Ser. B 39:83-93.

Hatziminaoglou, J., N. P. Zervas, and J. G. Boyazoglu. 1990. Prolific dairy sheep breeds in Greece. Options Méditerraneennes, Ser. A 12:25-30.

Kehrli, M. E., Jr., and J. P. Goff. 1989. Periparturient hypocalcemia in cows: Effects on peripheral blood neutrophil and lymphocyte function. J. Dairy Sci. 72:1188-1196.

Kimura, K., J. P. Goff, M. E. Jr. Kehrli, and J. A. Harp. 1999. Phenotype analysis of peripheral blood mononuclear cells in periparturient dairy cows. J. Dairy Sci. 82:315-319.

Kominakis, A., E. Rogdakis, and K. Koutsotolis. 1998. Genetic parameters for milk yield and litter size in Boutsiko dairy sheep. Can. J. Anim. Sci. 78:525-532.

Ploumi, K., S. Belibasaki, and G. Triantaphyllidis. 1998. Some factors affecting daily milk yield and composition in a flock of Chios ewes. Small Rumin. Res. 28:89-92.

Politis, I., I. Bizelis, and E. Rogdakis. 2002. The urokinase plasminogen activator system in ovine macrophages and neutrophils. Small Rumin. Res. 44:17-23.

Politis, I., I. Bizelis, A. Tsiaras, and A. Baldi. 2004. Effect of vitamin $\mathrm{E}$ supplementation on neutrophil function, milk composition and plasmin activity in dairy cows in a commercial herd. J. Dairy Res. 71:273-278.

Politis, I., M. Hidiroglou, T. R. Batra, J. A. Gilmore, R. C. Gorewit, and H. Scherf. 1995. Effects of vitamin $\mathrm{E}$ on immune system of dairy cows. Am. J. Vet. Res. 56:179-184. 
Politis, I., N. Hidiroglou, F. Cheli, and A. Baldi. 2001. Effects of vitamin $\mathrm{E}$ on urokinase-plasminogen activator receptor expression by bovine neutrophils. Am. J. Vet. Res. 62:1934-1938.

SAS Institute. 2004. SAS/STAT Software Version 9.0 for Windows. SAS Inst. Inc., Cary, NC.

Simos, E. N., E. M. Nikolaou, and P. E. Zoiopoulos. 1996. Yield, composition and certain physicochemical characteristics of milk of the Epirus mountain sheep breed. Small Rumin. Res. 20:67-74.
Smith, K. L., J. S. Hogan, and W. P. Weiss. 1997. Dietary vitamin $\mathrm{E}$ and selenium affect mastitis and milk quality. J. Anim. Sci. 75:1659-1665.

Steel, R. G. F., and J. H. Torrie. 1980. Principles and Procedures of Statistics: A Biometrical Approach. McGraw-Hill, New York, NY.

Theodorou, G., A. Kominakis, E. Rogdakis, and I. Politis. 2007. Factors affecting the plasmin-plasminogen system in milk obtained from three Greek dairy sheep breeds with major differences in their milk production capacity. J. Dairy Sci. 90:3263-3269. 